\title{
Logit Regression Approach to Rating Banks Using Financial Ratios: A Study of Gulf Cooperation Council Banks
}

\author{
Sree Rama Murthy $\mathrm{Y}^{1}$ \\ ${ }^{1}$ Department of Economics and Finance, CEPS, Sultan Qaboos University, Sultanate of Oman \\ Correspondence: Dr. Sree Rama Murthy Y, Assistant Professor, Department of Economics and Finance, CEPS, \\ Sultan Qaboos University, PO Box 20, PC 123, Sultanate of Oman. E-mail: murthy@squ.edu.om
}

Received: June 23, 2013

Accepted: September 2, 2013

Online Published: October 8, 2013

doi:10.5430/ijfr.v4n4p107

URL: http://dx.doi.org/10.5430/ijfr.v4n4p107

\begin{abstract}
Using seven ratios representing seven facets of bank financial management practices this paper rates and ranks the 68 commercial banks operating in Gulf Cooperation Council countries. Banks falling in the top quartile are rated higher than those in the next quartile. Logit regression technique is used to identify financial management practices of those banks which managed to remain in the top quartile both before and after the 2008 financial crisis.
\end{abstract}

Keywords: bank ratings, logit regression, financial ratios, GCC, gulf cooperation council, financial crisis

\section{Introduction}

This paper rates and ranks the 68 commercial bank operating in Gulf Cooperation Council (GCC) countries Bahrain, Kuwait, Oman, Qatar, Saudi Arabia and United Arab Emirates. Ranking is done for the years before and after the global financial crisis. Based on work published by Prefontaine et.al. (2002), seven ratios representing seven important facets of bank financial management practices are used for rating. The seven facets (see Table 1) and related ratios are: capital account management (represented by total capital adequacy ratio), credit and asset quality management (measured by ratio of impaired loans to total loans), interest rate risk management (measured using net interest margin), liquidity management (represented by ratio of liquid assets to customer \& short term funds), cost management (calculated by cost to income ratio), operational performance (represented by return on average assets), and finally profitability (as measured by return on average equity).

Banks falling in the top quartile in each ratio are rated higher compared to those in the next quartile. The focus of the paper is on financial management practices of those banks which managed to remain in the top quartile both before and after the global financial crisis. The paper uses the logit regression technique to analyse the ratios data of the 68 Gulf Cooperation Council (GCC) banks in order to identify which factors contribute most to ranking and rank changes.

Differences in behaviour between top rated and top ranked banks located in different countries before and after the financial crisis help us in learning important lessons about good financial management practices which are important for banks to remain healthy, viable and active.

\section{Review of Literature}

One strand of the literature on positioning of banks considers the behavior of bank liquidity in and around financial crises (Berger and Bowman, 2008; Campello, 2006; Lyandres, 2006; Brander and Lewis, 1986). An interesting finding in this literature is that financial crises can affect the competitive positioning of banks. Liquidity creation and adequate capital ratios can make the difference between survival and bust when regulatory agencies take firm action to save the banking system. Examining the pre-crisis capital and profitability ratios can give an indication of the competitive position of banks, and liquidity creation can play a major role in the post-crisis outcomes. Berger and Bowman (2008) study liquidity creation by U.S banks during, before and after five major bank crises. They obtain either a sharp increase or a sharp drop-off of liquidity before each crisis. Major banks are found to improve their liquidity market shares and profitability during the crises, improving their post-crisis competitive positions - 
something which did not happen during normal times. Even small banks with high capital ratios were seen to achieve this improvement.

While the work on the determinants of bank crises examines the link between changes in real economic (and monetary) variables and financial crises, another strand looks at the reverse link, the impact of the crisis on the real sector. Financial crises reduce credit and push up real interest rates, adversely affecting corporate investment - thus placing the economy firmly on the path to recession (Dell, Detragiache and Rajan, 2008; Bernanke and Gertler, 1989). Stock market downturns reduce wealth, and affect private consumption and investment (through the Tobin's Q effect). Export markets contract, so the crisis becomes global, the transmission also occurring through stock market linkages and reductions in inter-bank lending. These are, of course, the channels by which the current financial crisis affected the real economy also.

\section{Data and Methods}

Data for the paper was drawn from Bank Scope data base and the technique used is binary logit regression method. Year 2006 was identified as the pre crisis year and year 2009 was identified as the post crisis year for the study. E-Views software was used for the purpose of estimation of logit regressions. 68 banks operating in the GCC countries formed the initial sample for investigation. However due to non-availability of data and missing data only 51 banks are finally included in the sample.

Using the methodology suggested by Prefontaine, Thibeault and Bell (2002) for measuring performance of banks on various dimensions, we selected seven dimensions. The seven facets of bank financial management and related ratios are: capital account management represented by total capital adequacy ratio, credit and asset quality management measured by ratio of impaired loans to total loans, interest rate risk management measured using net interest margin, liquidity management represented by ratio of liquid assets to deposits, cost management calculated by cost to income ratio, efficiency represented by return on average assets, and finally profitability as measured by return on average equity.

Table 1

\begin{tabular}{ll}
\hline \multicolumn{1}{c}{ Symbol } & Ratio \\
\hline TCR & Total Capital Ratio \\
NIM & Net Interest Margin \\
ROA & Return on Assets \\
ROE & Return on Equity \\
CI & Cost to Income Ratio \\
NPA & Non Performing Assets Ratio - Impaired Loans to Gross Loans \\
LCST & Liquid Assets / Customer \& Short Term Funding \\
LD & Liquid Assets / Total Deposits \& Borrowings \\
TA & Total Assets (millions USD) \\
\hline
\end{tabular}


Table 2. Ratios and definitions

RATIO

\begin{tabular}{|c|c|c|}
\hline TCR & Total Capital Ratio & $\begin{array}{l}\text { This ratio is the total capital adequacy ratio under the Basle rules. It } \\
\text { measures Tier } 1+\text { Tier } 2 \text { capital which includes subordinated debt, } \\
\text { hybrid capital, loan loss reserves and the valuation reserves as a } \\
\text { percentage of risk weighted assets (credit risk +market risk }+ \text { operational } \\
\text { risk) and off balance sheet risks. }\end{array}$ \\
\hline NIM & Net Interest Margin & $\begin{array}{l}\text { This ratio is the net interest income expressed as a percentage of earning } \\
\text { assets. The higher this figure the cheaper the funding or the higher the } \\
\text { margin the bank is commanding. Higher margins and profitability are } \\
\text { desirable as long as the asset quality is being maintained. }\end{array}$ \\
\hline $\mathrm{ROA}$ & Return on Assets & $\begin{array}{l}\text { This is perhaps the most important single ratio in comparing the efficiency } \\
\text { and operational performance of banks as it looks at the returns generated } \\
\text { from the assets financed by the bank. }\end{array}$ \\
\hline $\mathrm{ROE}$ & Return on Equity & $\begin{array}{l}\text { The return on equity is a measure of the return on shareholder funds. } \\
\text { Obviously here the higher the figure the better but one should be careful in } \\
\text { putting too much weight on this ratio as it may be at the expense of an over } \\
\text { leveraged balance sheet. }\end{array}$ \\
\hline $\mathrm{CI}$ & Cost to Income Ratio & $\begin{array}{l}\text { This is one of the most focused on ratios currently and measures the } \\
\text { overheads or costs of running the bank, the major element of which is } \\
\text { normally salaries, as percentage of income generated before provisions. It } \\
\text { is a measure of efficiency although if the lending margins in a particuar } \\
\text { country are very high then the ratio will improve as a result. It can be } \\
\text { distorted by high net income from associates or volatile trading income. }\end{array}$ \\
\hline NPA & $\begin{array}{l}\text { Non Performing Assets } \\
\text { Ratio - Impaired Loans } \\
\text { to Gross Loans }\end{array}$ & $\begin{array}{l}\text { This is a measure of the amount of total loans which are doubtful. The } \\
\text { lower this figure is the better the assets quality. }\end{array}$ \\
\hline LCST & $\begin{array}{l}\text { Liquid Assets / } \\
\text { Customer \& Short Term } \\
\text { Funding }\end{array}$ & $\begin{array}{l}\text { This is a deposit run off ratio and looks at what percentage of customer and } \\
\text { short term funds could be met if they were withdrawn suddenly, the higher } \\
\text { this percentage the more liquid the bank is and less vulnerable to a classic } \\
\text { run on the bank. }\end{array}$ \\
\hline LD & $\begin{array}{l}\text { Liquid Assets / Total } \\
\text { Deposits \& Borrowings }\end{array}$ & $\begin{array}{l}\text { This ratio is similar to LCST but looks at the amount of liquid assets } \\
\text { available to borrower as well as depositors. }\end{array}$ \\
\hline TA & $\begin{array}{l}\text { Total Assets (millions } \\
\text { USD) }\end{array}$ & $\begin{array}{l}\text { Total assets measured in USD millions to allow cross country comparisons. } \\
\text { Converted from local currency into USD using exchange rates prevailing on } \\
\text { balance sheet date. }\end{array}$ \\
\hline
\end{tabular}

\section{DEFINITION}

For the purpose of ranking the banks a total score was first computed for each bank. The total score obtained by a bank is the sum of facet scores obtained on each of the seven facets. The score obtained by a bank in a particular facet depends on its position in that year within the quartiles. For example the facet score in respect of say variable NIM (Net Interest Margin) would be as follows: 4 if NIM is above the third quartile, 3 if NIM is between second and third quartile, 2 if NIM is between first and second quartile and 1 if NIM is below first quartile. For variables NIM, TCR, ROA, ROE, LD and LCST a higher value indicates better performance, while for NPA and CI a lower value indicates better performance, and therefore if NPA or CI is in the first quartile then it gets a facet score of 4 . Banks with higher score show better performance and are therefore higher ranked. The total scores obtained by summing the seven facet scores, by the 68 GCC banks in 2006 (pre-crisis year) and 2009 (post crisis year) are reported in Appendix A. 
Table 3. Quartile values of all GCC banks

\begin{tabular}{lrrrrrr}
\hline & \multicolumn{2}{c}{ First Quartile } & \multicolumn{2}{c}{ Median } & \multicolumn{2}{c}{ Third Quartile } \\
\hline & 2009 & 2006 & 2009 & 2006 & 2009 & 2006 \\
\hline Total Capital Ratio (TCR) & 15.25 & 15.4 & 17.6 & 18.2 & 21.65 & 22.65 \\
Net Interest Margin (NIM) & 2.22 & 2.71 & 2.84 & 3.3 & 3.57 & 3.96 \\
Return on Assets (ROA) & 0.51 & 2.24 & 1.32 & 3.12 & 2.14 & 3.7 \\
Return on Equity (ROE) & 3.17 & 13.6 & 11.24 & 19.57 & 15.9 & 35.73 \\
Cost to Income Ratio (CI) & 29.81 & 24.54 & 35.55 & 32.53 & 45.7 & 39.61 \\
Impaired Loans / Gross Loans & & & & & & \\
(NPA) & 2.22 & 1.21 & 3.67 & 1.95 & 7.03 & 3.96 \\
Liquid Assets / Customer \& ST & & & & & & \\
Funding (LCST) & 20.44 & 22.98 & 29.15 & 33.54 & 41.36 & 46.49 \\
Total Assets mil USD (TA) & 3238 & 2027 & 7882 & 5527 & 23574 & 20149 \\
\hline
\end{tabular}

Logit regression method was adopted to further analyse the data of the GCC banks. The purpose of logit regression is to identify which variables have a significant influence on ratings. Logit is a binary regression technique used for estimation in the presence of a qualitative dependent variable. In our case, the banks in the sample were divided into two groups. Banks in the top quartile were given a dependent variable value '1', and banks in the last two quartiles were given a value ' 0 '. Banks in the second quartile were dropped while estimating the logit regressions (restricted set). Fourteen banks which are in the top quartile were given a dependent variable value ' 1 ' and the rest ' 0 '. The logic of the values 1 and 0 in this case is to indicate that qualitatively a bank is either high ranked or low ranked. Whatever the method used to classify the banks into high and low ranked, the advantage of the logit regression is that it will be able to identify statistically significant variables which differentiate a low ranked bank from a high ranked bank. Independent variables used in the logit regression are the seven variables representing the seven dimensions of financial management practices plus total assets as a control variable for size.

\section{Binary Response Model Estimated using the Logit Technique}

$$
\mathrm{Ri}=\mathrm{Bo}+\mathrm{B} 1 * \mathrm{TCRi}+\mathrm{B} 2 * \mathrm{ROEi}+\mathrm{B} 3 * \mathrm{ROAi}+\mathrm{B} 4 * \mathrm{Cli}+\mathrm{B} 5 * \mathrm{NIMi}+\mathrm{B} 6 * \mathrm{LCSTi}+\mathrm{B} 7 * \mathrm{NPAi}+\mathrm{B} 8 * \mathrm{TAi}
$$

'where $\mathrm{Ri}$ is the rank of the bank (dependent variable can be either 0 or 1 in the logit regression; takes value 1 if bank is in the top rank and 0 otherwise)

For definition of other variables please refer to Table 2.

The logit regression allows us to focus on those facets of financial management practices which are most important for a bank to obtain a high rank. Assuming that our original ranking does differentiate between good and bad performance, the regression technique allows us to identify variables which lead to better performance.

Ordinary least squares method cannot be used in a situation when dependent variable takes only limited values. A limited dependent variable model using maximum likelihood estimation techniques is a good approach in such cases (Hill, Griffiths \& Judge, 2001). There is a choice between probit and logit when estimating nonlinear binary response models. The difference between the techniques is marginal (Woolridge, 2000) and many researchers prefer logit (Gujarati, 2003) and we followed the same path here.

Four logit regressions were estimated and are reported in the tables shown below. The first two (Logit 1 and Logit 2) use a restricted sample which includes only banks ranked in the top quartile and the lowest two quartiles. Banks occurring in the second quartile were deleted from the sample for the restricted sample regressions. The last two regressions reported (Logit 3 and Logit 4) are based on the full set sample of 68 banks which operate in the six GCC countries. However it is important to note that banks for which data is incomplete are automatically dropped by E-Views, the econometric software used for doing the binary logit regressions.

\section{Logit Regression Results and Analysis}

Of the four regression estimates (Table 4, 5, $6 \&$ 7) reported below "Logit Regression 1 Restricted Set' (Table 4) is the best. The reported LR test is based on the same concept as the F test in a linear model and if the related p-value is below .05 we conclude that the null hypothesis that all slope coefficients are simultaneously equal to zero gets rejected, implying that the independent variables included in the regression are able to explain the binary 
response behaviour. The conventional measure of goodness of fit (R2) is not particularly meaningful in binary dependent variable models. Measures similar to R2 such as McFadden R2, which ranges between 0 and 1, can be used in such situations.

The McFadden R squared value at 0.691148 and the LR Ratio (likelihood ratio) at 32.56 (p-value 0.0000079) indicate that we have a good fit in "Logit Regression 1 Restricted Set'. (Table 4)

Table 4. Logit regression 1 restricted set (2009)

\begin{tabular}{|c|c|c|c|c|c|}
\hline \multicolumn{6}{|c|}{ Dependent Variable: RANK } \\
\hline \multicolumn{6}{|c|}{ Method: ML - Binary Logit } \\
\hline Variable & Coefficient & Std. Error & z-Statistic & Prob. & \\
\hline $\mathrm{C}$ & -49.5514 & 25.51174 & -1.942296 & 0.0521 & $* * *$ \\
\hline ROE2009 & 1.093119 & 0.647189 & 1.689027 & 0.0912 & $* * *$ \\
\hline ROA2009 & 4.490322 & 3.060304 & 1.46728 & 0.1423 & \\
\hline CI2009 & 0.412636 & 0.213157 & 1.935826 & 0.0529 & $* * *$ \\
\hline TA2009 & $5.86 \mathrm{E}-05$ & 0.000055 & 1.065627 & 0.2866 & \\
\hline NIM2009 & 2.845626 & 2.251631 & 1.263807 & 0.2063 & \\
\hline LCST2009 & 0.223923 & 0.124831 & 1.793815 & 0.0728 & $* * *$ \\
\hline TCR2009 & -0.01183 & 0.278596 & -0.042456 & 0.9661 & \\
\hline NPA2009 & -1.00952 & 0.558521 & -1.807489 & 0.0707 & $* * *$ \\
\hline LR statistic ( $8 \mathrm{df})$ & 32.56053 & \multicolumn{2}{|c|}{ McFadden R-squared } & 0.691148 & \\
\hline Probability(LR stat) & 7.39E-05 & & & & \\
\hline Obs with Dep $=0$ & 21 & & & & \\
\hline Obs with Dep $=1$ & 14 & & & & \\
\hline
\end{tabular}

Goodness of fit is of secondary importance in binary response models, and what matters is the expected signs of the regressions coefficients and their statistical significance. (Gujarati, 2003). The z-values reported in front of each regression coefficient can read exactly the way we read t-values in standard OLS regressions estimates.

In the 'Logit Regression 1 Restricted Set' (Table 4) which is based on 2009 data, four variables are statistically significant at 10\% level: Cost to Income Ratio (CI), Non Performing Assets Ratio (NPA), Liquid Assets to Customer $\&$ Short Term Funding (LCST) and Return on Equity(ROE). The NPA variable has a negative sign as expected while the other three variables CI, LCST and ROE have a positive sign. What are the implications of these statistically significant variables (and their signs) is the subject of discussion in the paragraphs given below.

Table 6 shows the regression estimate for year 2009 using the full set of banks unlike Table 4 which is based on restricted set of banks. This regression indicates that three variables are statistically significant - cost to income ratio (CI), liquidity ratio (LCST) and non performing assets ratio (NPA). As expected NPA has a negative sign (in all regressions) indicating that higher non performing assets ratio which is due to impaired (bad) loans has a negative impact on a banks performance and therefore reduces its ranking. Good credit administration and protecting asset quality are important for a bank to achieve a good rating. Poor credit quality has a multiple impact on a bank. First poor credit quality and bad loans imply that the bank is not getting back what it has lent and is therefore loosing funds. Capital of the bank is getting eroded in the process. Further rotation of funds is not taking place and this is reducing the earning capacity of the bank, and ultimately profitability of the bank will get hit. Most importantly, since the loans were originally given by taking deposits or borrowing from the financial market, non performing loans imply that the bank will not have enough money to repay its liabilities, unless it has enough shareholders capital. In the long run a high level of non performing assets imply bankruptcy.

The cost to income ratio comes out with a positive sign in all the regressions and is statistically significant in the 2009 regressions. Cost as measured in this ratio is mostly overheads which consists of staff expenses and administrative expenses. A higher cost to income ratio should normally result in lower return on assets and is therefore sometimes seen to be bad from a bank's performance point of view. One issue to note while looking at banks in the GCC countries is that cost to income ratios of Gulf Arab banks have always been low compared to international averages. The watermark for cost to income ratio is 50\% (Ernst \& Young, 2010) and any bank which is able to reduce cost to income ratio below the $50 \%$ watermark is seen to be doing a good job in controlling costs. 
Table 3 reports the average cost to income ratio of top quartile GCC banks. The data in Table 3 indicates that both in 2006 (pre-crisis) and 2009 (post crisis) the cost to income ratios of GCC banks are quite low (in the range of 27 to 35 percent) compared to the fifty percent watermark. The positive coefficient of the cost to income ratio in all regressions indicates that although Gulf Arab banks as a group are able to achieve low cost to income ratios, within those banks the ones which spend more on staff and administration are able to achieve better ranking than others. One possible explanation for this result is that good banks are better staffed and better administered and therefore better managed leading to better performance and profitability.

Return on equity (ROE) is another variable which is statistically significant in the 2009 regression (Table 4). This result is not at all surprising. The positive coefficient indicates that a high ROE leads to good ranking. Profits and profitability (ROE or ROA) are key factors in ensuring good performance. Profits are important not only in the short term but also in the long term as continued profitability contributes to capital growth, which in turn allows a bank to achieve higher asset growth. Only when shareholders are rewarded adequately we can say that a bank has performed well and this is what this regression is saying. However it would be dangerous to say that profit alone is a measure of good ranking. When looking at profits and profitability (ROE or ROA) we need to note that these variables are focusing only on the return aspect without looking at the risk side. A good bank should not only give good profits but should also be stable and strong. The 2009 regression reported in Table 4 is the post crisis period regression, and seems to be clearly saying that during a period of crisis good profitability is important for survival and growth, a conclusion which any rating agency will readily agree.

Liquidity variable is also statistically significant in the 2009 regression (Table 4). The coefficient is positive indicating that a higher liquidity ratio leads to better ranking. The statistical significance of the ratio also indicates that better ranked banks had higher liquidity ratios as compared to lower ranked banks. A high level of liquidity allows a bank to continue lending aggressively without fear of problems in case of a run on the bank. During a crisis period, the volatility in the financial markets increases risk perceptions among customers which could lead to sudden withdrawal of deposits and at the same time money may not be available in the money markets for a bank to pull through a period of liquidity crunch. Therefore during such periods a bank needs to maintain sufficiently high level of liquidity and also needs to monitor liquidity levels closely. If money market and inter-bank market is active and there is sufficient liquidity available through external source, which would be the situation during normal times (pre-crisis), high levels of liquidity are not so important. The statistical significance of the LCST variable tells us that good liquidity management is important for a bank especially if the economy is going through a crisis period, but may not be important in normal times as brought out by the 2006 regression results (Table 5)

Table 5. Logit regression 2 - restricted set (2006)

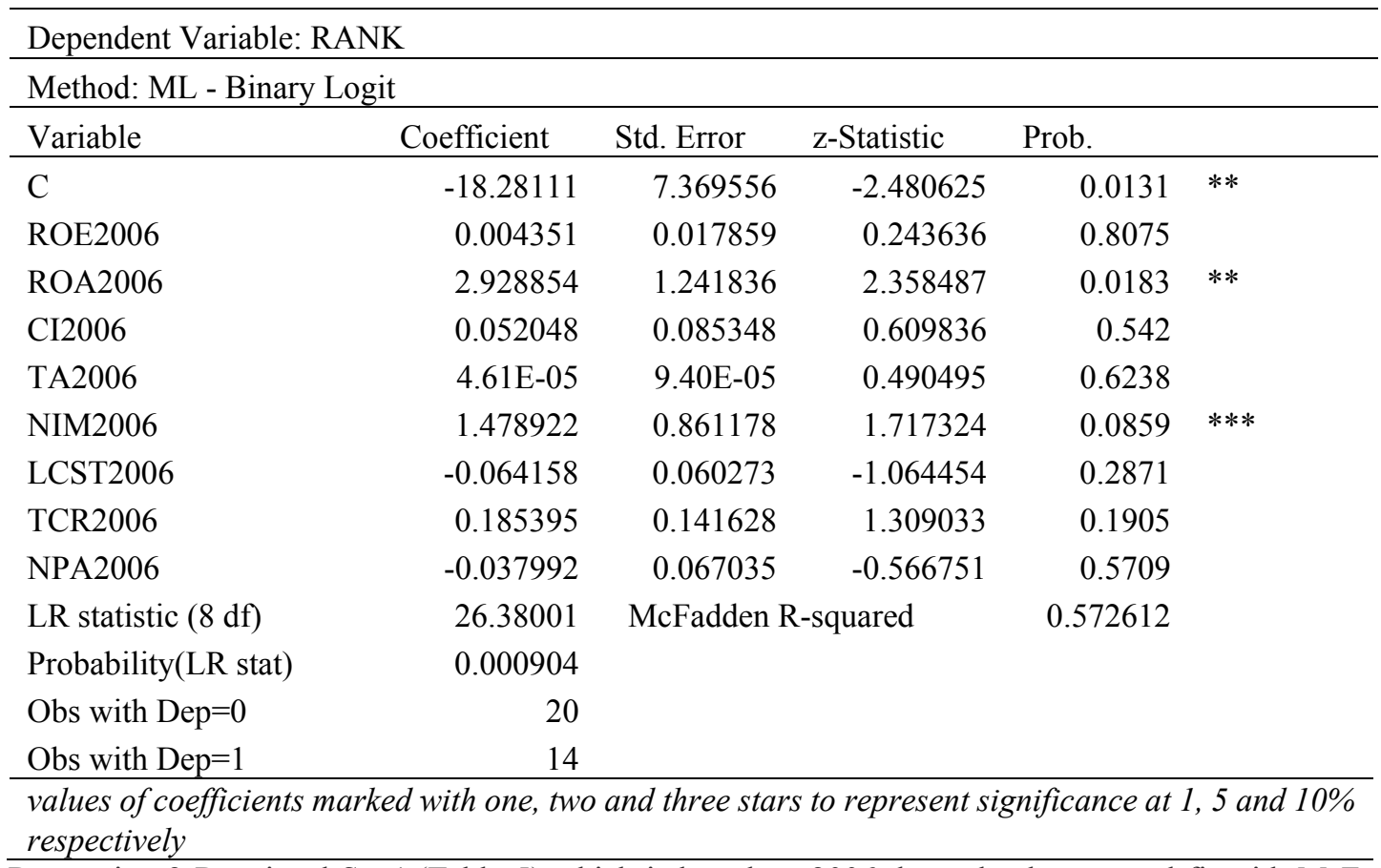

'Logit Regression 2 Restricted Set ' (Table 5) which is based on 2006 data, also has a good fit with McFadden R Squared at 0.57 and LR ratio at 26.38 (p-value .000904). Statistically significant variables which contributed to good ranking are Return on Assets and Net Interest Margin in 2006. Variables which were effective in ensuring that a 
bank performs well in the pre-crisis period are quite different from the post crisis (2009) period variables. In the pre crisis (2006) period the Gulf economies were booming, with reasonably high economic growth rates and good business performance. In such a situation bad loans and lack of liquidity are not big problem issues for banks. Since external factors and economic wide factors are not impinging on a bank's performance, variables which contribute to profit such as return on assets and net interest margins differentiate good banks from bad banks. This is what the logit regression results (Table 5) seem to be saying - in good times every body does well, but those who are able generate higher interest margins and are able generate better returns on assets will occupy top ranking positions.

The full set regression for year 2006 (Table 7) is not well estimated and has a low McFadden R Squared and insignificant LR ratio and is therefore not worth discussing.

Table 6. Logit regression 3 full set (2009)

\begin{tabular}{|c|c|c|c|c|c|}
\hline \multicolumn{6}{|c|}{ Dependent Variable: RANK } \\
\hline \multicolumn{6}{|c|}{ Method: ML - Binary Logit } \\
\hline Variable & Coefficient & Std. Error & z-Statistic & Prob. & \\
\hline $\mathrm{C}$ & -17.9633 & 8.141503 & -2.206391 & 0.0274 & $* *$ \\
\hline ROE2009 & 0.274494 & 0.226471 & 1.21205 & 0.2255 & \\
\hline ROA2009 & 1.583874 & 1.737219 & 0.911729 & 0.3619 & \\
\hline CI2009 & 0.121565 & 0.068595 & 1.772205 & 0.0764 & $* * *$ \\
\hline TA2009 & $-1.67 \mathrm{E}-05$ & $2.99 \mathrm{E}-05$ & -0.55881 & 0.5763 & \\
\hline NIM2009 & 1.379905 & 1.268446 & 1.087871 & 0.2767 & \\
\hline LCST2009 & 0.076908 & 0.045993 & 1.672165 & 0.0945 & $* * *$ \\
\hline TCR2009 & 0.098769 & 0.172067 & 0.574015 & 0.566 & \\
\hline NPA2009 & -0.41421 & 0.222686 & -1.86005 & 0.0629 & $* * *$ \\
\hline LR statistic (8 df) & 26.90732 & \multicolumn{2}{|c|}{ McFadden R-squared } & 0.469991 & \\
\hline Probability(LR stat) & 0.000734 & & & & \\
\hline Obs with Dep $=0$ & 33 & & & & \\
\hline Obs with Dep $=1$ & 14 & & & & \\
\hline \multicolumn{6}{|c|}{$\begin{array}{l}\text { values of coefficients marked with one, two and three stars to represent significance at 1, } 5 \text { and } 10 \% \\
\text { respectively }\end{array}$} \\
\hline \multicolumn{6}{|c|}{ 7. Logit regression 4 full set (2006) } \\
\hline \multicolumn{6}{|c|}{ Dependent Variable: RANK } \\
\hline \multicolumn{6}{|c|}{ Method: ML - Binary Logit } \\
\hline Variable & Coefficient & Std. Error & z-Statistic & Prob. & \\
\hline $\mathrm{C}$ & -0.22574 & 2.358914 & -0.095698 & 0.9238 & \\
\hline ROE2006 & 0.003992 & 0.006825 & 0.584881 & 0.5586 & \\
\hline ROA2006 & -0.5281 & 0.482454 & -1.094604 & 0.2737 & \\
\hline CI2006 & -0.05017 & 0.041332 & -1.213901 & 0.2248 & \\
\hline TA2006 & $-7.38 \mathrm{E}-05$ & 4.92E-05 & -1.500644 & 0.1334 & \\
\hline NIM2006 & 0.844725 & 0.524801 & 1.609609 & 0.1075 & \\
\hline LCST2006 & -0.02293 & 0.027935 & -0.82098 & 0.4117 & \\
\hline TCR2006 & 0.088013 & 0.075457 & 1.166396 & 0.2435 & \\
\hline NPA2006 & -0.10524 & 0.111301 & -0.945547 & 0.3444 & \\
\hline LR statistic (8 df) & 9.326498 & \multicolumn{2}{|c|}{ McFadden R-squared } & 0.167145 & \\
\hline Probability(LR stat) & 0.315506 & & & & \\
\hline Obs with Dep $=0$ & 31 & & & & \\
\hline Obs with Dep=1 & 14 & & & & \\
\hline
\end{tabular}


In the post crisis period - economies are recovering from bad times, businesses are doing are just coming out of a bad period and in general growth is slow. The variables which make a difference between good banks and bad banks in such a situation would be control over non- performing assets and availability of high liquidity. As expected the 2009 post crisis regression does indicate that banks which were able to reduce non performing assets and were able to cap impaired loans did better than other banks. Highly liquid banks are able to perform better because in a crisis period, depositors become highly sensitive to new information and a bank may suddenly face problems of liquidity when risk perceptions change for the worse. Further, higher levels of impaired loans would imply that the banks funds are not rotating, and expected inflows from repayment of loans and payment of interest by loan customers is not coming through creating a liquidity problem, which can be overcome only if the bank anticipates problems and remains liquid throughout the crisis period. The positive coefficient of the cost to income ratio in all regressions indicates that those banks which spend more on staff and administration are able to achieve better ranking than others. One possible explanation for this result is that good banks are better staffed and better administered and therefore better managed leading to higher business growth, superior operational performance and higher profitability.

\section{Conclusions}

The 2009 post crisis regression results indicate that good liquidity management and tight control over impaired loans (non-performing assets) are important financial management practices for a bank to successfully sail through a financial crisis. From the cost side the regression results imply that spending on overheads is beneficial for GCC banks as this leads to better staffing, better management, better loan administration and therefore lower NPAs. Poorly staffed banks are likely to suffer most during a financial crisis. As the saying goes, "if you pay peanuts you will get monkeys".

While the need for better NPA management, and continuous emphasis on profitability are not surprising results, what differentiates the results of this paper from conventional thinking are the liquidity management and cost management aspects. Behavior of bank liquidity in and around financial crises, importance of liquidity management during crisis periods and the major role played by liquidity creation in post-crisis outcomes has been pointed in some recent papers. (Berger and Bowman, 2008; Campello, 2006; Lyandres, 2006; Brander and Lewis, 1986). There is definitely a need for new thinking in the area of liquidity management, and need for recognition of the importance of this facet of bank financial management.

One needs to note that the conclusions are specific to GCC banks and cannot be applied to banks in other regions without further empirical investigaton.

\section{References}

Albertazzi, U., \& Gambcorta, L. (2006). Bank profitability and the business cycle. Banca D'Italia, Discussion paper available at SSRN-id 935026.

Bank of Sharjah, Annual Reports 2005 to 2010.

Berger, A.N., \& Bowman, C.H.S. (2008). Financial crises and bank liquidity creation. mimeo, University of South Carolina and Case Western Reserve University.

Bernanke, B.S., \& Gertler, M. (1989). Agency costs, net worth and business fluctuations. American Economic Review, 79, 14-31.

Branden, J.A., \& Lewis, T.R. (1986). Oligopoly and financial structure: the limited liability effect. American Economic Review, 76, 956-970.

Cole, R.A., \& Gunther, J.W. (1995, September). Separating the likelihood and timing of bank failire. Journal of Banking and Finance, 19, 1073-89. http://dx.doi.org/10.1016/0378-4266(95)98952-M

Cornett, M.M., \& Tehranian, H. (1994). A examination of voluntary versus involuntary security issuances by commercial banks: The impact of capital regulations on common stock returns. Journal of Financial Economics, 35, 99-122. http://dx.doi.org/10.1016/0304-405X(94)90019-1

Dell' Ariccia, G., E. Detragiache., \& Rajan, R. (2008). The real effects of banking crises. Journal of Financial Intermediation, 17, 89-112. http://dx.doi.org/10.1016/j.jfi.2007.06.001

Demiruguc-Kunt, A., Detragiache, E., \& Gupta, P. (2006). Inside the crisis: an empirical study of banking systems in distress. Journal of International Money and Finance, 25, 702-718. http://dx.doi.org/10.1016/j.jimonfin.2006.04.004

DeYoung, R. (2003, Oct.). De Novo Bank Exit. Journal of Money, Credit, and Banking, 717. 
Diamond, D. W., \& Dybvig, P.H. (1983). Bank runs, deposit insurance and liquidity. Journal of Political Economy, 91, 401-19. http://dx.doi.org/10.1086/261155

Ernst \& Young. (2010). Banking Agenda November 2010. Retrieved from http://www.ey.com/Publication/vwLUAssets/Pub_Banking_Agenda_November/\$FILE/FS_Pub_Banking_Agen da_November.pdf

Gambocorta, L., \& Mistruli, P.E. (2004). Does bank capital effect lending behaviour? Journal of Financial Intermediation, 13, 436-457. http://dx.doi.org/10.1016/j.jfi.2004.06.001

Gonzallez-Hermossilo, B., Pazarbasioglu, C., \& Billings, R. (1997, September). Determinants of banking system fragility: a case study of Mexico. IMF Staff Papers, 44, 295-314. http://dx.doi.org/10.2307/3867561

Goudreau, R.E. (1992). FYI - Commercial bank profitability rises as interest margins and securities sales increase. Economic Review, Federal Reserve Bank of Atlanta, May - June, 33-52.

Gujarati, D. (2003). Basic Econometrics. McGraw Hill Irwin.

Halsem, J.A., Scheraga, C.A., \& Bedingfield, J.P. (1992). An analysis of the foreign and domestic balance sheet strategies of the US banks and their association to profitability performance. Management International Review, $32(1), 55-76$.

Hill, C.R., Griffith, W.E., \& Judge, G.G. (2001). Undergraduate Econometrics. John Wiley.

Jacklin, C.J., \& Bhattacharya, S. (1988, June). Distinguishing panics and information-based bank runs: welfare and policy implications. Journal of Political Economy, 96, 568-91. http://dx.doi.org/10.1086/261552

Kaminsky, G.L., \& Reinhart, C.M. (1998). Financial crises in Asia and Latin America: Then and Now. American Economic Review, 88, 444-448.

Kanaya, A., \& Woo, D. (2000). The Japanese banking crisis of the 1990s: sources and lessons. IMF Working paper WP/00/7, International Monetary Fund, January.

Kim, M., \& Kim, I.W. (1997). The structure profit relationship of commercial banks in South Korea and the United States: A comparative study. Multinational Business Review, 5(2), 81-94.

Myers, S.C., \& Majluf, N.S. (1984). Corporate finance and investment decisions when firms have information that investors do not have. Journal of Financial Economics, 13, 187-221. http://dx.doi.org/10.1016/0304-405X(84)90023-0

Prefontaine, J., Thibeault, A., \& Bell, R. (2002). Introduction to Bank Financial Management. The Institute of Canadian Bankers.

Santomero, A. (1997). Commercial Bank Risk Management: An Analysis of the Process. Wharton Financial Institutions Center, The Wharton School, University of Pennsylvania.

Sarkar, S., \& Sriram, R. (2001). Bayesian models for early warning of bank failures. Management Science, 47(11), 1457-76. http://dx.doi.org/10.1287/mnsc.47.11.1457.10253

Seabright, P., Fries, S., \& Neven, J. (2002). Performance in transition economies. Davidson Institute Working Paper Number 505.

Shen, C.H., \& Chang, Y.H. (2006). Do regulations affect banking performance? Government governance may matter. Contemporary Economic Policy, 24(1), 92-105. http://dx.doi.org/10.1093/cep/byj013

Stein, J.C. (1998). An adverse selection model of bank asset and liability management with implications for the transmission of monetary policy. RAND Journal of Economics, 29, 466-486. http://dx.doi.org/10.2307/2556100

Sundararajan, V., \& Tomas, B. (1991). Issues in banking crises. In V. Sundararajan and B. Tomas (Eds.), Banking Crises: Cases and Issues. International Monetary Fund, Washington D.C.

Tripe, D. (1997). Cost to Income Ratios in Australasian Banking, Monograph, Center for Banking Studies, Massey University. Retrieved from http://centre-banking-studies.massey.ac.nz/fileadmin/research.../CosttoIncome.PD

Van den Heuvel, S.J. (2003, May). Does bank capital matter for monetary transmission. Federal Reserve Bank of New York Economic Policy Review, 258-265.

Woolridge, J.M. (2000). Introductory Econometrics: A Modern Approach. Thomson South Western.

Zakrajsek, E. (2002, June). Profits and Balance Sheet Developments at US commercial banks in 2000. Federal Reserve Bulletin, 243-270. 
Appendix A. GCC banks and their ranking using scores

(4 Banks which remained top ranked before and after the financial crisis are:

Bank of Sharjah, National Bank of Kuwait, Oman International Bank and

National Commercial Bank (Saudi Arabia)

Bank Name

Bank of Sharjah

National Bank of Bahrain

RAKBANK-National Bank of Ras Al-Khaimah (P.S.C.)

(The)

Oman Arab Bank SAOG

National Bank of Umm Al-Qaiwain

First Gulf Bank

Commercial Bank of Dubai P.S.C.

National Bank of Kuwait S.A.K.

Oman International Bank

Riyad Bank

Union National Bank

Doha Bank

National Bank of Abu Dhabi

Commercial Bank of Qatar (The) QSC

BBK B.S.C.

Al Masraf-Arab Bank for Investment \& Foreign Trade

National Commercial Bank (The)

Samba Financial Group

Al Khalij Commercial Bank

Arab National Bank

Qatar National Bank

National Bank of Fujairah

National Bank of Oman (SAOG)

Mashreqbank

Banque Saudi Fransi

Ahli Bank QSC

Arab Banking Corporation BSC

Bank Dhofar SAOG

Future Bank B.S.C.

Al Hilal Bank PJSC

Emirates NBD PJSC

Saudi British Bank (The)
Ranking using

Ctry Scores

$\mathrm{AE}$
$\mathrm{BH}$

AE

$\mathrm{OM}$

$\mathrm{AE}$

$\mathrm{AE}$

AE

KW

OM

SA

AE

QA

AE

QA

$\mathrm{BH}$

AE

SA

SA

QA

SA

QA

$\mathrm{AE}$

OM

$\mathrm{AE}$

SA

QA

$\mathrm{BH}$

$\mathrm{OM}$

$\mathrm{BH}$

$\mathrm{AE}$

$\mathrm{AE}$

SA
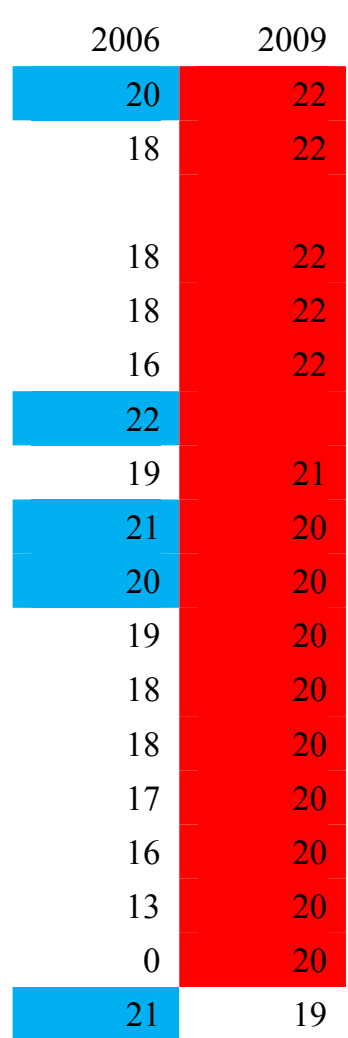

19

19

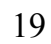

19

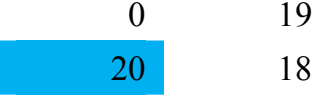

$19 \quad 18$

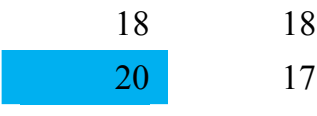

$19 \quad 17$

$17 \quad 17$

$15 \quad 17$

$13 \quad 17$

$13 \quad 17$

$12 \quad 17$

$\begin{array}{ll}0 & 17\end{array}$

$\begin{array}{ll}0 & 17\end{array}$

22 
Gulf International Bank BSC

$\begin{array}{lrr}\text { BH } & 17 & 16 \\ \text { KW } & 15 & 16 \\ \text { BH } & 14 & 16 \\ \text { OM } & 0 & 16 \\ \text { SA } & 22 & 15 \\ \text { AE } & 14 & 15 \\ \text { BH } & 20 & 14 \\ \text { OM } & 17 & 14 \\ \text { KW } & 17 & 13 \\ \text { BH } & 15 & 13 \\ \text { SA } & 19 & 12 \\ \text { AE } & 14 & 12 \\ \text { SA } & 13 & 12 \\ \text { KW } & 17 & 11 \\ \text { KW } & 19 & 9 \\ \text { QA } & 19 & 0 \\ \text { QA } & 19 & 0 \\ \text { BH } & 18 & 0 \\ \text { AE } & 0 & 0\end{array}$

